\title{
KAPASITAS PERANGKAT DESA DALAM PENYELENGGARAAN PEMERINTAHAN DESA DI KABUPATEN KUDUS
}

\section{Capacity Forces Village Village In The Implementation Of Government In The District Kudus}

\author{
Asrori \\ Badan Penelitian dan Pengembangan Kemendagri \\ Jl. Kramat Raya No. 132 - Senen, Jakarta, Telp./Faks: +62 21314 0454; \\ Email: asrori2011@yahoo.com, Tlp.08159693156 \\ Dikirim: 18 Maret 2014; direvisi: 25 Maret 2014; disetujui: 12 Mei 2014
}

\begin{abstract}
Abstrak
Untuk mengetahui kapasitas perangkat desa dalam menyelenggarakan pemerintahan desa dapat dilakukan dengan pemetaan perangkat desa. Penelitian ini dilaksanakan dengan tujuan untuk mengetahui kapasitas perangkat desa dalam penyelenggaraan pemerintahan; kendala, dan langkah-langkah yang telah dan akan dilakukan oleh Pemerintah Daerah Kabupaten Kudus untuk meningkatkan kapasitas perangkat desa dalam menyelenggarakan pemerintahan desa. Penelitian ini bersifat deskriptif analisis dengan pendekatan kualitatif di tiga kecamatan kabupaten Kudus, yaitu Kecamatan Dawe, Jekulo dan Kecamatan Undaan, dengan sampel 26 desa. Hasil studi antara lain menunjukkan bahwa tingkat pemahaman perangkat desa dalam memahami majemen sumber daya manusia maupun kemampuan teknis perangkat desa masih kurang. Mayoritas perangkat desa belum mengikuti pendidikan dan pelatihan/bimbingan teknik kompetensi, karena memiliki masa kerja lebih dari 10 tahun perangkat desa merasa sudah memiliki tingkat pengetahuan yang memadai.

Kata kunci: kapasitas, perangkat desa, pemerintahan desa.
\end{abstract}

\begin{abstract}
To know capacity of the publik service in the village, engage to conduct with the mapping the village. This research was conducted in order to know the capacity the publik service of the village in governance; obstacles and the steps that have been conducted and will be carried out by local government for increasing the capacity of the district Kudus for organizing village government. Describtive analised with kuantitative approach are used in this research in the three sub-districts Kudus, the District Dawe, Jekulo and District Undaan and also takes 26 villages for sampling. The results of the research shows that knowlage of publik service staffs to understand human resources management and technical capacity of the village are still lacking. Mostly, the villages have not followed some educations and trainings/mentorings technical competency yet, because they feel if when they have experiences over 10 years the village, educations and trainng is not nececcery to follow.

Keywords: capacity, forces village, village government.
\end{abstract}

\section{PENDAHULUAN}

Peraturan Pemerintah Nomor 72 Tahun 2005 tentang Desa, menyebutkan bahwa desa adalah kesatuan masyarakat hukum yang memiliki batasbatas wilayah yang berwenang untuk mengatur dan mengurus kepentingan masyarakat setempat, berdasarkan asal-usul dan adat istiadat setempat yang diakui dan dihormati dalam sistem Pemerintahan Negara Kesatuan Republik Indonesia. Desa bukanlah bawahan kecamatan, karena kecamatan merupakan bagian dari perangkat daerah kabupaten/kota, dan desa bukan merupakan bagian dari perangkat daerah. Pemerintahan desa terdiri atas pemerintah desa (yang meliputi kepala desa dan perangkat desa) dan Badan Permusyawaratan Desa (BPD).

Regulasi sistem pemerintahan nasional sebagaimana diatur dalam Undang-Undang Nomor 32 Tahun 2004 dan Peraturan Pemerintah Nomor 72
Tahun 2005, kedudukan desa menjadi sangat strategis, hal ini ditandai dengan adanya pelimpahan kewenangan yang cukup luas dari pemerintah kabupaten/kota. Delegasi atau pelimpahan kewenangan pada dasarnya merupakan sebuah proses untuk membagi kewenangan ke bawah dalam sebuah organisasi.

Pemerintah desa sebagai penyelenggara pemerintahan terdepan dalam melaksanakan urusan kabupaten/kota yang diserahkan kepada desa diperlukan adanya kapatisitas perangkat desa yang memadai. Sedangkan penyelenggaraan pemerintahan desa yang baik sulit untuk terwujud bilamana kapasitas aparatur pemerintah desa tidak memadai, tanpa kapasitas yang memadai mereka akan gagal dalam menjalankan tugas dan fungsi desa. namun demikian sampai saat ini secara umum kapasitas perangkat desa belum diketahui secara pasti. 
Dalam Kamus Hukum dan Glosarium Otonomi Daerah, kapasitas diartikan sebagai: "kemampuan seseorang atau individu, suatu organisasi atau suatu sistem untuk menjalankan tugas dan fungsi serta kewenangannya untuk mencapai tujuannya secara efektif dan efisien. Dalam Kerangka Nasional Pengembangan dan Peningkatan Kapasitas Pemerintah dalam Rangka Mendukung Desentralisai, Kebijakan Menteri Dalam Negeri dan Kepala Bappenas, Tahun 2002 disebutkan bahwa pengembangan dan peningkatan kapasitas meliputi tiga tingkatan, yaitu: 1) Tingkat sistem, yaitu kerangka peraturan dan kebijakan-kebijakan yang mendukung atau membatasi pencapaian tujuan-tujuan kebijakan tertentu; 2) Tingkat kelembagaan atau entitas, yaitu struktur organisasi, proses-proses pengambilan keputusan dalam organisasi, prosedur dan mekanisme kerja, instrumen manajemen, hubungan-hubungan dan jaringan antar organisasi, dll; 3) Tingkat individu, yaitu tingkat keterampilan, kualifikasi, pengetahuan/ wawasan, sikap (attitude), etika dan motivasi individu yang bekerja dalam suatu organisasi.

Pusat Kajian Kinerja Otonomi Daerah pada tahun 2008, melaksanakan Kajian Peningkatan Kapasitas Pemerintahan Desa dengan kesimpulan, bahwa: belum semua desa menyusun dokumen dokumen perencanaan; penerimaan keuangan desa masih sangat bergantung dari transfer pemerintah yang ada di atasnya; kapasitas aparatur desa dalam penyusunan kebijaksanaan desa masih sangat rendah; pembuatan keputusan oleh kepala desa belum berdasar pada azas manajemen modern; dan dalam penyelenggaraan pelayanan publik, pemerintahan desa menghadapi keterbatasan kapasitas manajemen administratif (kualitas dan kuantitas sumber daya manusia aparatur desa yang berpengaruh pada produktifitas dan kreatifitas aparatur desa) (http://kejobongkec.blogspot.com/2011/10/kapasitasaparatur-desa.html).

Hasil survey pendahuluan di Kabupaten Kudus, menunjukkan bahwa keberadaan pemerintah desa belum dapat berfungsi secara optimal dalam penyelenggaraan pemerintahan desa. Salah satu faktor belum optimalnya penyelenggaraan pemerintahan desa disebabkan oleh kapasitas perangkat desa yang kurang memadai jika dibandingkang dengan beban tugas, luas wilayah dan ketrampilan yang mereka miliki masih sangat terbatas sebagai akibat minimnya pembinaan, penataran dan dan diklat teknis untuk meningkatkan kemampuan perangkat desa. Potret perangkat desa menunjukkan profesionalisme rendah, kurang kreatif dan inovatif, serta masih banyak potret negatif lainnya yang intinya menunjukkan bahwa perangkat desa masih lemah.

Secara kualitas, perangkat desa saat ini relative masih rendah, dilihat dari tingkat pendidikan mayoritas tamat SMP, bahkan masih dijumpai yang tidak lulus SD. Sedangkan khusus untuk pendidikan Sekdes, $11 \%$ Tamat SD; 63\% Tamat SLTP; $13 \%$ Tamat SLTA; 9\% Tamat S-1; dan 0,5\% Tamat S-2
(Persadaan Girsang, 2012). Di samping kualitas, secara kuantitas perangkat desa juga relative masih rendah. Keterbatasan perangkat desa baik secara kualitas maupun kuantitas sangat berpengaruh terhadap kemampuan perangkat desa dalam menjalankan tugas dan fungsinya. Di lain pihak tingkat kesejahteraan perangkat desa yang secara umum relatif masih rendah, serta belum adanya dukungan APBD yang memadai untuk penyelenggaraan pemerintahan desa. Untuk mengetahui kapasitas perangkat desa dalam penyelenggaraan pemerintahan desa dapat dilakukan melalui pemetaan kapasitas perangkat desa.

Penelitian ini dilaksanakan dengan tujuan untuk mengetahui kapasitas perangkat desa dalam penyelenggaraan pemerintahan; kendala, dan langkahlangkah yang telah dan akan dilakukan oleh Pemerintah Daerah Kabupaten Kudus untuk meningkatkan kapasitas perangkat desa dalam menyelenggarakan pemerintahan desa. Pemetaan dibatasi pada 1) peta aspek individu (kemampuan dasar, kemampuan managemen, kemampuan teknis); 2) peta aspek institusi/kelembagaan; dan 3) peta aspek peralatan.

Pemerintahan desa adalah penyelenggaraan urusan pemerintahan oleh pemerintah desa dan Badan Permusyawaratan Desa dalam mengatur dan mengurus kepentingan masyarakat setempat berdasarkan asal-usul dan adat istiadat setempat yang diakui dan dihormati dalam sistem Pemerintahan Negara Kesatuan Republik Indonesia (NKRI). Urusan pemerintahan yang menjadi kewenangan Desa mencakup urusan pemerintahan yang sudah ada berdasarkan hak asal-usul desa, urusan pemerintahan yang menjadi kewenangan kabupaten/kota yang diserahkan pengaturannya kepada desa, tugas pembantuan dari pemerintah dan pemerintah daerah, urusan pemerintah lainnya yang oleh peraturan perundangan-undangan yang diserahkan kepada desa.

Pemerintah desa merupakan unit terdepan dan berhadapan langsung dalam pelayanan pemerintahan dan pemberdayaan masyarakat, serta menjadi tonggak utama untuk keberhasilan semua program pemerintah. Memperkuat desa merupakan suatu upaya untuk mempercepat terwujudnya kesejahteraan masyarakat. Dalam upaya meningkatkan kapasitas pelayanan kepada masyarakat, selain mendudukkan desa menurut urusan pemeriantahan yang menjadi kewenangan desa, kepastian tersedianya pendanaan untuk menyelenggarakan pemerintahan dan pemberdayaan masyarakat serta tersedianya SDM yang mampu menyelenggarakan pelayanan kepada masyarakat.

Pemerintah desa atau yang disebut dengan nama lain adalah kepala desa dan perangkat desa sebagai unsur penyelenggara pemerintahan desa. Perangkat desa terdiri dari sekretaris desa dan perangkat desa lainnya. Perangkat desa bertugas membantu kepala desa dalam melaksanakan tugas dan wewenangnya. 
perangkat desa bertanggung jawab kepada kepala desa.

Kapasitas atau kapabilitas adalah sebuah ukuran kemampuan dari seseorang atau institusi dalam menjalankan fungsinya (http://suryokocolink. wordpress.com/2010/10/11/peningkatan-kapasitaspemerintah-desa/).

Istilah "kemampuan" mempunyai banyak makna, Jhonson dalam (Cece Wijaya,1991:3) berpendapat bahwa "kemampuan adalah perilaku yang rasional untuk mencapai tujuan yang dipersyaratkan sesuai kondisi yang diharapkan". Sementara itu, menurut Kartono (1993: 13) bahwa "kemampuan adalah segala daya, kesanggupan, kekuatan dan keterampilan teknik maupun sosial yang dianggap melebihi dari anggota biasa”. Lebih lanjut, Syarif (1991: 8) menyebutkan beberapa jenis kemampuan yang antara lain: kecerdasan, menganalisis, bijaksana mengambil keputusan, kepemimpinan/kemasyarakatan dan pengetahuan tentang pekerjaan.

Mengacu pada pengertian dan jenis kemampuan tersebut di atas, maka dalam suatu organisasi pemerintahan Desa senantiasa perlu memiliki suatu daya kesanggupan, keterampilan, pengetahuan terhadap pekerjaan dalam pengimplementasian tugastugas dan fungsi masing-masing aparat Desa. Kemampuan yang penulis maksudkan adalah kemampuan yang dilihat dari hasil kerjanya atau kemampuan kerjanya. Kemampuan kerja seseorang menurut Tjiptoherianto (1993: 36) mengemukakan bahwa "kemampuan kerja yang rendah adalah akibat dari rendahnya tingkat pendidikan, dan latihan yang dimiliki serta rendahnya derajat kesehatan".

Sementara itu, menurut Steers dalam (Rasyid, 1992: 6) bahwa "kemampuan aparatur pemerintah sebenarnya tidak terlepas dari pembicaraan tingkat kematangan aparatur yang didalamnya menyangkut keterampilan yang diperoleh dari pendidikan latihan dan pengalaman".

Berdasarkan pandangan tersebut jelas bahwa kemampuan seseorang, dalam hal ini aparat desa dapat dilihat dari tingkat pendidikan aparat, jenis latihan yang pernah diikuti dan pengalaman yang dimilikinya. Secara konsepsional hal ini diperkuat dari pandangan Steers tersebut sebelumnya bahwa untuk mengidentifikasi apakah kegiatan dalam organisasi dapat mencapai tujuannya salah satunya yang harus mendapat perhatian adalah orang-orang yang ada dalam organisasi tersebut.

Selanjutnya Steers berpendapat bahwa pada kenyataannya anggota organisasi yang merupakan faktor yang mempunyai pengaruh yang paling penting dalam pencapaian tujuan organisasi disebabkan orangorang itulah yang menggerakkan roda organisasi. Anggota organisasi yang dimaksud adalah aparat desa yang merupakan faktor yang paling menentukan keberhasilan pelaksanaan tugas-tugas yang dibebankan kepadanya.

Pemerintah Desa memiliki peran signifikan dalam pengelolaan proses sosial di dalam masyarakat.
Tugas utama yang harus diemban pemerintah desa adalah bagaimana menciptakan kehidupan demokratik, memberikan pelayanan sosial yang baik sehingga dapat membawa warganya pada kehidupan yang sejahtera, rasa tenteram dan berkeadilan. Guna mewujudkan tugas tersebut, pemerintah desa dituntut untuk melakukan perubahan, baik dari segi kepemimpinan, kinerja birokrasi yang berorientasi pada pelayanan yang berkualitas dan bermakna, sehingga kinerja pemerintah desa benar-benar makin mengarah pada praktek good local governance, bukannya bad governance.

Pengembangan dan peningkatan kapasitas dalam Kerangka Nasional Pengembangan dan Peningkatan Kapasitas mengacu kepada kebutuhan akan; penyesuaian kebijakan-kebijakan dan peraturanperaturan, reformasi kelembagaan, modifikasi prosedur-prosedur kerja dan mekanisme-mekanisme koordinasi, peningkatkan keterampilan dan kualifikasi sumber daya manusia, perubahan sistem nilai dan sikap atau perilaku sedemikian rupa, sehingga dapat terpenuhinya tuntutan dan kebutuhan otonomi daerah, sebagai suatu cara pendekatan baru ke arah pemerintahan, pengadministrasian dan pengembangan mekanisme-mekanisme partisipatif yang tepat guna memenuhi tuntutan yang lebih demokratis. Dengan demikian Kerangka Nasional Pengembangan dan Peningkatan Kapasitas mengarahkan pemerintah daerah, dan dalam hal ini pemerintah desa untuk mengembangkan dan meningkatan kerangka kerja pemerintahan secara keseluruhan guna memenuhi tuntutan tugas dan kewenangan yang diberikan.

Dimensi peningkatan kapasitas perangkat desa mencakup penguasaan pengetahuan, keterampilan dan wawasan yang diperoleh melalui pendidikan, latihan, belajar dan pengalaman.

Tiga tingkat kemampuan yang harus dimiliki oleh perangkat desa yaitu: 1) kemampuan dasar; 2) kemampuan manajemen; dan 3) kemampuan kemampuan teknis. Kemampuan dasar yang harus dimiliki perangkat desa adalah meliputi: pengetahuan tentang regulasi desa, pengetahuan tentang dasar-dasar pemerintahan desa, dan pengetahuan tentang tugas pokok dan fungsi. Kemampuan manajemen meliputi: manajamen SDM, manajemen pelayanan publik, manajamen asset, dan managemen keuangan. Sedangkan Kemampuan Teknis meliputi: penyusunan administrasi desa, penyusunan perencanaan pembangunan, penyusunan anggaran, penyusunan Perdes, dan pelayanan publik.

\section{METODE PENELITIAN}

Penelitian ini bersifat deskriptif analisis dengan pendekatan kualitatif. Penelitian ini mengambil kasus di Kabupaten Kudus, dengan mengambil sampel 26 desa dari 3 (tiga) kecamatan, yaitu Kecamatan Dawe, Jekulo dan Kecamatan Undaan. Informan dan responden dalam studi ini adalah Kepala Bagian Pemerintahan Desa Sekretaris Daerah, dan Kepala 
urusan Pemerintahan di Kecamatan, Kepala Desa, Sekretaris Desa, Kepala Urusan di Desa, Kepala Dusun dan tokoh masyarakat. Data yang diperlukan dalam penelitian ini yaitu data primer dan data sekunder. Teknik analisis data dilakukan dengan menggunakan analisis interpretatif menggambarkan data dan naratif.

\section{HASIL DAN PEMBAHASAN}

\section{Kapasitas Perangkat Desa}

Pemerintah desa merupakan unit terdepan dan berhadapan langsung dalam pelayanan pemerintahan dan pemberdayaan masyarakat, serta menjadi tonggak utama untuk keberhasilan semua program pemerintah. Sebagai unit penyelenggaraan pemerintahan terbawah, maka profesionalisme perangkat desa mutlak dibutuhkan, mengingat tugas dan fungsi desa yang harus diemban oleh aparatur desa cukup komplek, antara lain adalah mengatur pemerintahan, pembangunan dan masyarakat agar tercipta "keteraturan dan ketertiban", pelayanan: mengurus kepentingan dan kebutuhan masyarakat guna mendukung kesejahteraan serta meningkatkan kekuatan dan potensi masyarakat agar masyarakat bisa mandiri dan sejahtera.

\section{Profil Perangkat Desa}

Tabel 1. Usia Perangkat Desa

\begin{tabular}{ccr}
\hline Usia Perangkat & \multicolumn{2}{c}{ Frekwensi } \\
\cline { 2 - 3 } Desa (Tahun) & Jumlah & $\%$ \\
\hline Kurang 30 & 10 & 4,1 \\
$30-34$ & 14 & 5,8 \\
$35-39$ & 31 & 12,8 \\
$40-44$ & 45 & 18,5 \\
$45-49$ & 45 & 18,5 \\
$50-54$ & 33 & 13,6 \\
$55-59$ & 25 & 10,3 \\
Lebih 60 & 40 & 16,4 \\
Total & 243 & 100,0 \\
\hline
\end{tabular}

Usia perangkat desa bervariatif, yaitu berusia kurang dari 30 tahun $4,1 \%$; berusia antara dari $30 \mathrm{~s} / \mathrm{d}$ 34 tahun 5,8\%; berusia antara dari 35 s/d 39 tahun $12,8 \%$; berusia antara dari $40 \mathrm{~s} / \mathrm{d} 44$ tahun $18,5 \%$; berusia antara dari $45 \mathrm{~s} / \mathrm{d} 49$ tahun 18,5\%; berusia antara dari $50 \mathrm{~s} / \mathrm{d} 54$ tahun 13,6\%; berusia antara dari $55 \mathrm{~s} / \mathrm{d} 59$ tahun 10,3\%; dan berusia lebih dari 60 tahun $16,4 \%$.

Mengacu pada pernyataan Steers dalam bahwa kemampuan aparatur pemerintah sebenarnya tidak terlepas dari pembicaraan tingkat kematangan aparatur yang didalamnya menyangkut keterampilan yang diperoleh dari pendidikan latihan dan pengalaman, maka kemampuan perangkat desa diwilayah sampel dilihat dari tingkat pendidikan dan pengalaman teridentifikasi, bahwa tingkat pendidikan perangkat desa, kapasitas perangkat desa cukup memadai, dimana 40,8\% berpendidikan SLTA, 29,5\% berpendidikan SLTP, 4,9\% berpendidikan Sarjana dan Sarjana Muda/D3, sedangkan perangkat desa yang berpendidikan SD hanya 21,4\%. Sedangkan pengalaman perangkat desa berdasarkan masa kerja perangkat desa sudah memadai, yaitu yang masa kerja rata-rata lebih dari 10 tahun, bahkan yang masa kerjanya lebih dari 35 mencapai 5,8\%. Sedangkan yang kurang dari 10 tahun hanya $2,1 \%$.

Tabel 2. Tingkat Pendidikan Perangkat Desa

\begin{tabular}{ccr}
\hline Tingkat Pendidikan & \multicolumn{2}{c}{ Frekwensi } \\
\cline { 2 - 3 } & Jumlah & \multicolumn{1}{c}{21,4} \\
\hline SD & 52 & 32,9 \\
SLTP/sederajat & 80 & 40,8 \\
SMA/sederajat & 99 & 4,9 \\
S1/D3 & 12 & 100,0 \\
Total & 243 &
\end{tabular}

Tabel 3. Masa Kerja Perangkat Desa

\begin{tabular}{crr}
\hline Masa Kerja (Tahun) & \multicolumn{2}{c}{ Frekwensi } \\
\cline { 2 - 3 } & Jumlah & $\%$ \\
\hline Kurang 5 & - & - \\
$5-9$ & 5 & 2,1 \\
$10-14$ & 40 & 16,4 \\
$15-19$ & 49 & 20,1 \\
$20-24$ & 52 & 21,4 \\
$25-29$ & 61 & 25,1 \\
$30-34$ & 22 & 9,1 \\
Lebih 35 & 14 & 5,8 \\
Total & 243 & 100,0 \\
\hline
\end{tabular}

\section{Aspek Individu}

Dimensi peningkatan kapasitas perangkat desa mencakup penguasaan pengetahuan, keterampilan dan wawasan yang diperoleh melalui pendidikan, latihan, belajar dan pengalaman. Sedangkan tingkat kempuan yang harus dimiliki oleh perangkat desa dalam penelitian ini mencakup 1) Kemampuan dasar, yang meliputi: pengetahuan tentang regulasi desa, pengetahuan tentang dasar-dasar pemerintahan desa, dan pengetahuan tentang tugas pokok dan Fungsi; 2) Kemampuan managemen, yang meliputi: managamen SDM, managemen pelayanan publik, managamen asset dan managemen keuangan 3) Kemampuan kemampuan teknis, yang meliputi: penyusunan administrasi desa, penyusunan perencanaan pembangunan, penyusunan anggaran, penyusunan perdes, dan pelayanan publik.

\section{a. Kemampuan dasar}

Kinerja pemerintah desa merupakan hasil interaksi yang kompleks dan agregasi kinerja sejumlah individu (perangkat desa). Pencapaian kinerja dipengaruhi kemampuan dan motivasi. Determinan kemampuan adalah pengetahuan dan ketrampilan. Sementara motivasi ditentukan oleh faktor sikap dan 
situasi lingkungan kerja. Pengetahuan diukur melalui tingkat pendidikan, diklat/penataran/bintek.

Dilihat dari pengalaman, mayoritas perangkat desa memiliki pengalaman yang memadai $(97,9 \%$ memiliki masa kerja lebih dari 10 tahun) dan ditunjang dengan tingkat pendidikan yang cukup, yaitu mayoritas lulus SLTP dan SLTA $(73,7 \%)$, sehingga perangkat desa merasa memiliki kemampuan yang baik terkait dengan dasar regulasi desa, dasardasar pemerintahan desa, dan tugas pokok dan fungsi dalam penyelenggaraan pemerintah desa. Namun demikian pengalaman dan pendidikan perangkat desa kurang ditunjang dengan peningkatan ketrampilan melalui diklat/penataran/bintek. Perangkat desa bekerja berdasarkan kebiasaan, sedangkan peraturan yang menjadi dasar pekerjaan yang mereka lakukan selama ini telah mengalami perubahan yang sangat signifikan.

Perangkat desa yang sudah mengikuti diklat/penataran/bintek peningkatan kemampuan dasar sangat rendah, yaitu dari 78 informan perangkat desa, hanya $17,9 \%$ yang pernah mengikuti, dan belum mengikuti $82,1 \%$. Dengan perincian yang pernah mengikuti diklat/penataran/bintek regulasi desa 4 orang, dasar-dasar pemerintahan desa 4 orang, dan yang pernah mengikuti diklat/penataran/bintek tugas pokok dan fungsi 6 orang. Sedangkan yang belum pernah mengikuti diklat/penataran/bintek regulasi desa mencapai 22 orang, dasar-dasar pemerintahan desa 22 orang, dan yang pernah pernah mengikuti diklat/penataran/bintek tugas pokok dan fungsi 20 orang.

Persepsi perangkat desa terhadap tingkat pengetahuan dasar (regulasi desa, dasar-dasar pemerintahan desa, dan tugas pokok dan fungsi) perangkat desa cukup memadai, yaitu: $34,6 \%$ sudah memahami, 32,1\% cukup memahami, 16,7\% kurang memahami pengetahuan dasar, dan $15,4 \%$ menyatakan tidak tahu.

\section{1) Kemampuan Regulasi Desa}

Mayoritas atau $84 \%$ perangkat desa belum pernah mengikuti diklat/penataran/ bintek peningkatan kemampuan dasar regulasi desa, dan yang sudah pernah mengikuti diklat/penataran/bintek peningkatan kemampuan dasar regulasi desa baru $15,4 \%$. Perangkat desa yang sudah mengikuti diklat/penataran/bintek peningkatan kemampuan dasar tersebut berasal dari Desa Kuwukan, Desa Ternadi, Desa tanjung Rejo, Desa Pladen, Desa Klaling, Desa Wates, Desa Undaan Lor dan Desa Tanjung rejo.

Kapasitas perangkat desa dalam penyelenggaraan pemerintahan desa dilihat dari kemampuan dasar dalam memahami regulasi desa cukup bervariasi, yaitu $34,4 \%$ perangkat desa cukup memahami regulasi desa, 30,8\% perangkat desa memahami regulasi desa, 19,2\% perangkat desa kurang memahami regulasi desa, dan 15,4\% perangkat desa tidak menjawab.
Dari hasil konfirmasi (wawancara) terkait dengan jawaban persepsi perangkat desa (tabel 4.5), ternyata tingkat pemahaman perangkat desa terhadap regulasi desa yang mereka maksudkan terbatas pada regulasi yang dibuat oleh pemerintah desa yaitu Peraturan Desa dan Keputusan Kepala Desa. Sedangkan saat ditanyakan pengetahuan mereka terkait dengan kebijakan regulasi desa yang sudah dikeluarkan oleh Pemerintah Kabupaten Kudus antara lain adalah:

a) Perda Kabupaten Kudus Nomor 9 Tahun 2008 Tentang Perubahan Atas Perda Kabupaten Kudus Nomor 17 Tahun 2006 Tentang Keuangan Desa;

b) Perda Kabupaten Kudus Nomor 13 Tahun 2006 Tentang Pedoman Penyusunan Organisasi Dan Tata Kerja Pemerintahan Desa;

c) Perda Kabupaten Kudus Nomor 5 Tahun 2007 Tentang Perencanaan Pembangunan Desa;

d) Perda Kabupaten Kudus Nomor 17 Tahun 2006 Tentang Keuangan Desa;

e) Perda Kabupaten Kudus Nomor 18 Tahun 2006 Tentang Badan Permusyawaratan Desa;

f) Perda Kabupaten Kudus Nomor 19 Tahun 2006 Tentang Pencalonan, Pemilihan, Pengangkatan, Pelantikan, Dan Pemberhentian Kepala Desa;

g) Perda Kabupaten Kudus Nomor 20 Tahun 2006 Tentang Pengisian Dan Pemberhentian Perangkat Desa;

h) Perda Kabupaten Kudus Nomor 21 Tahun 2006 Tentang Kedudukan Keuangan Kepala Desa Dan Perangkat Desa;

i) Perbup Kudus Nomor 1 Tahun 2007 Tentang Petunjuk Pelaksanaan Perda Kabupaten Kudus Nomor 18 Tahun 2006 Tentang Badan Permusyawaratan Desa;

j) Perbup Kudus Nomor 1 Tahun 2008 Tentang Petunjuk Pelaksanaan Perda Kabupaten Kudus Nomor 20 Tahun 2006 Tentang Pengisian Dan Pemberhentian Perangkat Desa;

k) Perbup Kudus Nomor 2 Tahun 2007 Tentang Petunjuk Pelaksanaan Perda Kabupaten Kudus Nomor 21 Tahun 2006 Tentang Kedudukan Keuangan Kepala Desa Dan Perangkat Desa;

1) Perbup Kudus Nomor 10 Tahun 2007 Tentang Petunjuk Pelaksanaan Perda Kabupaten Kudus Nomor 13 Tahun 2006 Tentang Pedoman Penyusunan Organisasi Dan Tata Kerja Pemerintahan Desa;

Ketika dikonfirmasi terhadap 12 (dua belas) rugulasi diatas mayoritas perangkat desa belum mengetahui kebijakan regulasi desa yang sudah dikeluarkan oleh Pemerintah Kabupaten Kudus tersebut secara keseluruhan, hanya sebagian kecil yang mereka ketahui, seperti: Pedoman Penyusunan Organisasi Dan Tata Kerja Pemerintahan Desa; Kedudukan Keuangan Kepala Desa Dan Perangkat Desa; Perencanaan Pembangunan Desa; Keuangan Desa. Kurangnya 
Tabel 4. Keikutsertaan Perangkat Desa terhadap Diklat/Penataran/Bintek Peningkatan Kemampuan Dasar

\begin{tabular}{|c|c|c|c|c|c|c|c|c|c|}
\hline \multirow{3}{*}{\multicolumn{2}{|c|}{ Diklat/Penataran/Bintek }} & \multicolumn{6}{|c|}{ Frekwensi Jawaban Responden } & \multicolumn{2}{|c|}{ Total } \\
\hline & & \multicolumn{2}{|c|}{ Sudah } & \multicolumn{2}{|c|}{ Belum } & \multicolumn{2}{|c|}{$\begin{array}{c}\text { Tidak Jawab/ } \\
\text { Tahu }\end{array}$} & \multirow[b]{2}{*}{$\mathrm{Jlh}$} & \multirow[b]{2}{*}{$\%$} \\
\hline & & Jlh & $\%$ & $\mathrm{Jlh}$ & $\%$ & Jlh & $\%$ & & \\
\hline 1 & Regulasi Desa & 4 & 15,4 & 22 & 84,6 & - & - & 26 & 100,0 \\
\hline 2 & $\begin{array}{l}\text { Dasar-Dasar } \\
\text { Pemerintahan Desa }\end{array}$ & 4 & 15,4 & 22 & 84,6 & - & - & 26 & 100,0 \\
\hline 3 & Tugas Pokok \& Fungsi & 6 & 23,1 & 20 & 76,9 & - & - & 26 & 100,0 \\
\hline & Total & 14 & 17,9 & 64 & 82,1 & - & - & 78 & 100,0 \\
\hline
\end{tabular}

Sumber: Data Primer

Tabel 5. Persepsi Perangkat Desa terhadap Tingkat Pengetahuan Dasar yang Dimiliki Perangkat Desa

\begin{tabular}{|c|c|c|c|c|c|c|c|c|c|c|c|}
\hline \multirow{3}{*}{\multicolumn{2}{|c|}{$\begin{array}{c}\text { Tingkat Pengetahuan Dasar } \\
\text { yang Dimiliki Perangkat } \\
\text { Desa }\end{array}$}} & \multicolumn{8}{|c|}{ Frekwensi Jawaban Responden } & \multirow{2}{*}{\multicolumn{2}{|c|}{ Total }} \\
\hline & & \multicolumn{2}{|c|}{ Mahami } & \multicolumn{2}{|c|}{ Cukup } & \multicolumn{2}{|c|}{ Kurang } & \multicolumn{2}{|c|}{$\begin{array}{c}\text { Tidak Jawab/ } \\
\text { Tahu }\end{array}$} & & \\
\hline & & $\mathrm{Jlh}$ & $\%$ & Jlh & $\%$ & $\mathrm{Jlh}$ & $\%$ & $\mathrm{Jlh}$ & $\%$ & Jlh & $\%$ \\
\hline 1 & Regulasi Desa & 8 & 30,8 & 9 & 34,6 & 5 & 19,2 & 4 & 15,4 & 26 & 100,0 \\
\hline 2 & $\begin{array}{l}\text { Dasar-Dasar } \\
\text { Pemerintahan Desa }\end{array}$ & 4 & 15,4 & 11 & 42,3 & 6 & 23,1 & 5 & 19,2 & 26 & 100,0 \\
\hline 3 & $\begin{array}{l}\text { Tugas Pokok \& } \\
\text { Fungsi }\end{array}$ & 15 & 57,7 & 5 & 19,2 & 3 & 11,5 & 3 & 11,5 & 26 & 100,0 \\
\hline & Total & 27 & 34,6 & 25 & 32,1 & 13 & 16,7 & 12 & 15,4 & 78 & 100,0 \\
\hline
\end{tabular}

Sumber: Data Primer

pemahaman tersebut mayoritas responden menyatakan selama ini perangkat desa kurang mendapatkan sosialisasi regulasi desa yang telah dikeluarkan oleh pemerintah kabupaten, provinsi maupun pemerintah pusat. Dari hasil konfirmasi dari perangkat desa dari unsur kewilayah dan unsur pelaksana teknis, mereka bahkan tidak mengetahui/belum mendengar terhadap keberadaan Perda yang mengatur tentang desa.

\section{2) Kemampuan Dasar-Dasar Pemerintahan Desa}

Keikutsertaan perangkat desa dalam mengikuti diklat/penataran/bintek peningkatan kemampuan dasar-dasar pemerintahan desa, mayoritas masih sangat rendah sekali, yaitu hanya $15,4 \%$ mengikuti diklat/penataran/bintek peningkatan kemampuan dasar-dasar pemerintahan desa, belum pernah mengikuti mencapai 84,6\%. Namun demikian persepsi mereka terhadap tingkat pemahaman dasar-dasar pemerintahan desa cukup baik dan baik mencapai, yaitu $57,7 \%$.

\section{3) Kemampuan Dasar Memahami Tugas Pokok Dan Fungsi}

Keikutsertan perangkat desa dalam mengikuti diklat/penataran/bintek peningkatan kemampuan tugas pokok dan fungsi sebagai perangkat desa juga masih sangat rendah, yaitu baru $23,1 \%$. Besarnya perangkat desa yang belum pernah mengikuti diklat/bintek kemampuan dasar tersebut disebabkan keterbatasan sumber daya yang dimiliki oleh Pemda Kabupaten (Bagian Pemerintahan Sekretaris Daerah Kabupaten), sehingga mayoritas perangkat desa belum mengikuti diklat peningkatan kemampuan dasar. Walaupun keikutsertan perangkat desa dalam mengikuti diklat/bintek masih rendah, tetapi mayoritas perangkat desa merasa sudah memahami tugas pokok dan fungsi pemerintah desa $(57,7 \%$ memahami dan $19,2 \%$ cukup memahami).

Persepsi pemahaman perangkat desa terhadap dasar-dasar pemerintahan desa tersebut, hanya terfokus pada pemahaman aktifitas yang mereka lakukan sehari-hari, seperti pemahaman terhadap tugas dan fungsi mereka sebagai perangkat desa sebagaimana diatur dalam Perda, Perbup, dan Perdes, serta pemahaman pelaksanaan administrasi umum seperti kegiatan pencatatan mengenai kegiatan-kegiatan pemerintahan desa, administrasi keuangan desa (APBDes), dan administrasi desa.

Berdasarkan rutinitas melaksanakan pekerjaan sehari-hari dengan masa kerja rata-rata diatas 10 tahun, perangkat desa merasa memiliki kemampuan yang baik dalam hal dasar regulasi desa, dasar-dasar pemerintahan desa, dan tugas pokok dan fungsi. Namun demikian kompetensi yang mereka miliki belum cukup mampu untuk melaksanakan tugas-tugas penyelenggaraan 
Tabel 6. Keikutsertaan Perangkat Desa Terhadap Diklat/Penataran/ Bintek Peningkatan Kemampuan Manajemen

\begin{tabular}{|c|c|c|c|c|c|c|c|c|c|}
\hline & \multirow{3}{*}{ Diklat/ Penataran/Bintek } & \multicolumn{6}{|c|}{ Frekwensi Jawaban Responden } & \multirow{2}{*}{\multicolumn{2}{|c|}{ Total }} \\
\hline & & \multicolumn{2}{|c|}{ Sudah } & \multicolumn{2}{|c|}{ Belum } & \multicolumn{2}{|c|}{$\begin{array}{c}\text { Tidak } \\
\text { Jawab/Tahu }\end{array}$} & & \\
\hline & & $\mathrm{Jlh}$ & $\%$ & Jlh & $\%$ & $\mathrm{~J} / \mathrm{h}$ & $\%$ & Jlh & $\%$ \\
\hline 1 & Manajemen SDM & 4 & 15,4 & 22 & 84,6 & - & 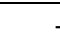 & 26 & 100,0 \\
\hline 2 & Manajemen Pelayanan Publik & 5 & 19,2 & 21 & 80,8 & - & 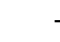 & 26 & 100,0 \\
\hline 3 & Manajemen Asset & 6 & 23,1 & 20 & 76,9 & - & - & 26 & 100,0 \\
\hline \multirow[t]{2}{*}{4} & Manajemen Keuangan & 6 & 23,1 & 20 & 76,9 & - & . & 26 & 100,0 \\
\hline & Total & 21 & 20,2 & 83 & 79,8 & - & - & 104 & 100,0 \\
\hline
\end{tabular}

Sumber: Data Primer

Tabel 7. Persepsi Perangkat Desa Terhadap Tingkat Pengetahuan Manajemen

\begin{tabular}{|c|c|c|c|c|c|c|c|c|c|c|c|}
\hline & \multirow{3}{*}{ Tingkat Pengetahuan } & \multicolumn{8}{|c|}{ Frekwensi Jawaban Responden } & \multirow{2}{*}{\multicolumn{2}{|c|}{ Total }} \\
\hline & & \multicolumn{2}{|c|}{ Memahami } & \multicolumn{2}{|c|}{ Cukup } & \multicolumn{2}{|c|}{ Kurang } & \multicolumn{2}{|c|}{$\begin{array}{c}\text { Tidak } \\
\text { Jawab/Tahu }\end{array}$} & & \\
\hline & & Jlh & $\%$ & Jlh & $\%$ & Jlh & $\%$ & Jlh & $\%$ & Jlh & $\%$ \\
\hline 1 & Manajemen SDM & 6 & 23,1 & 13 & 50,0 & 4 & 15,4 & 3 & 11,5 & 26 & 100,0 \\
\hline 2 & $\begin{array}{l}\text { Manajemen Pelayanan } \\
\text { Publik }\end{array}$ & 11 & 42,3 & 9 & 34,6 & 3 & 11,5 & 3 & 11,5 & 26 & 100,0 \\
\hline 3 & Manajemen Asset & 7 & 26,9 & 10 & 38,5 & 4 & 15,4 & 5 & 19,2 & 26 & 100,0 \\
\hline 4 & Manajemen Keuangan & 11 & 42,3 & 8 & 30,8 & 5 & 19,2 & 2 & 7,4 & 26 & 100,0 \\
\hline \multicolumn{2}{|c|}{ Kemampuan manajemen } & 35 & 33,6 & 40 & 38,5 & 16 & 15,4 & 13 & 12,5 & 104 & 100,0 \\
\hline
\end{tabular}

Sumber: Data Primer

pemerintahan desa. Pengalaman perangkat desa yang sudah baik, tetapi kurang ditunjang dengan diklat/bintek kemampuan dasar pemerintahan desa tidak sebanding dengan regulasi kebijakan pemerintahan desa yang ada saat ini. Mereka kurang memiliki pengetahuan terhadap regulasi kebijakan pemerintahan desa, baik regulasi yang dibuat di provinsi, maupun di kabupaten.

Kapasitas sekdes dan kepala urusan dalam penyelenggaraan pemerintah desa dilihat dari kemampuan dasar lebih baik dibandingkan dengan perangkat desa dari unsur kewilayahan (Kepala Dusun) dan pelaksana teknis lapangan (Kebayan, Pembantu Kebayan, Ladu, Pembantu Ladu, Modin dan pembantu Modin).

Rendahnya keikutsertaan perangkat desa dalam mengikuti diklat/bintek terkait dengan kemampuan dasar Pemerintahan Desa, berdampak pada terbatasnya jumlah kebijakan desa yang disusun baik dari segi kuantitas maupun kualitas. Dalam penyusunan kebijakan desa belum mencerminkan tahapan dari proses penyusunan peraturan desa. Kemampuan perangkat desa dalam menyusun regulasi desa, baik dalam hal perencanaan, pelaksanaan, maupun dalam penyusunan Perdes dan Keputusan Kades masih rendah.

Bagian Pemerintahan Sekretaris Daerah dan Badan Pemberdayaan Masyarakat dan Keluarga Berencana Kabupaten Kudus sebagai instansi yang bertanggung jawab dalam melakukan pembinaan dan fasilitasi bagi pemerintah desa belum mampu melakukan sosialisasi, pelatihan/bintek dan simulasi tentang penyusunan kebijakan desa secara optimal, karena keterbatasan sumber-sumber daya yang dimiliki oleh institusi tersebut.

\section{b. Kemampuan Managemen}

Salah satu kapasitas perangkat desa dapat dilihat dari tingkat kemampuan managemen yang harus dimiliki, baik managamen SDM, managamen asset, managemen pelayanan publik, dan managemen keuangan. Dari hasil identifikasi data lapangan diketahui keikutsertaan perangkat desa pada diklat/penataran/bintek peningkatan kemampuan manajemen sangat rendah.

Perangkat desa yang sudah mengikuti diklat/penataran/bintek peningkatan kemampuan manajemen masih sangat rendah, yaitu dari 104 informan perangkat desa hanya 20,2\%, dan perangkat desa yang belum mengikuti diklat/penataran/bintek peningkatan kemampuan dasar sebesar 79,8\%. Adapun yang pernah mengikuti diklat/penataran/bintek manajemen SDM 4 orang, manajemen pelayanan publik 5 orang, manajemen asset 6 orang, dan yang pernah mengikuti diklat/penataran/bintek manajemen keuangan 6 orang. Sedangkan yang belum pernah mengikuti diklat/penataran/bintek manajemen SDM 22 orang, manajemen pelayanan publik 21 orang, manajemen asset 20 orang, dan yang pernah mengikuti 
diklat/penataran/bintek manajemen keuangan 20 orang.

Persepsi perangkat desa terhadap tingkat pengetahuan manajemen (manajemen SDM, manajemen pelayanan publik, manajemen asset, dan manajemen keuangan) perangkat desa cukup memadai, yaitu: $38,5 \%$ tingkat pengetahuan dasar perangkat desa dinilai cukup memahami, 33,6\% sudah memahami, $15,4 \%$ perangkat desa kurang memahami pengetahuan dasar terkait dengan, dan $12,7 \%$ menyatakan tidak tahu.

\section{1) Kemampuan Manajemen SDM}

Tingkat keikutsertaan perangkat desa dalam mengikuti diklat/bintek peningkatan kemampuan manajemen mayoritas masih rendah, dimana perangkat desa yang pernah mengikuti diklat/penataran/bintek manajemen SDM hanya $15,4 \%$. Namun demikian mayoritas persepsi perangkat desa terhadap tingkat pengetahuan manajemen SDM sudah memadai, yaitu 50,0\% cukup baik dan, 23,1\% baik. Persepsi perangkat desa yang merasa dirinya sudah memiliki kemampuan yang memadai dalam mengelola manajemenSDM. dengan alasan pada dasarnya perangkat desa tidak memiliki staf dan kalaupun ada hanya satu atau dua orang, sehingga tidak memiliki beban tugas untuk mengelola sumber daya atau peningkatan kemampuan perangkat desa, baik dari segi kulaitas maupun kuantitas. Tugas untuk meningkatkan kemampuan perangkat desa, seperti proses perencanaan pendidikan, pelatihan dan pengelolaan perangkat desa untuk mencapai hasil yang optimal menjadi tanggungjawab kepala desa dan sekdes. Sedangkan penguasaan SDM, bagi perangkat desa adalah bagaimana dapat meningkatkan kemampuannya dalam melaksanakan tugasnya. Masa kerja dan pengalaman yang lama belum memberikan pemahaman perangkat desa secara signifikan dalam memahami majemen SDM.

\section{2) Kemampuan Manajemen Pelayanan Publik}

Tingkat keikutsertaan perangkat desa dalam mengikuti diklat/penataran/bintek peningkatan kemampuan manajemen pelayanan publik mayoritas masih rendah, yaitu hanya 19,2\%, yang pernah ikut. Kondisi ini menunjukkan bahwa pembinaan perangkat desa selama ini masih kurang mendapat perhatian. Namun demikian mayoritas persepsi perangkat desa terhadap pemahaman majemen pelayanan publik dianggap sudah memadai $(76,9)$, dimana $42,3 \%$ sudah memahami dan $34,6 \%$ cukup memahami manajemen pelayanan publik.

Mayoritas persepsi perangkat desa terhadap kemampuan perangkat desa dalam manajemen pelayanan yang memadai tersebut, karena pemahaman perangkat desa pada pengertian manajemen pelayanan, adalah pelayanan yang mereka berikan kepada masyarakat selama ini, yaitu perangkat desa berusaha melayani masyarakat dengan sebaik-baiknya. Pelayanan yang dilakukan perangkat desa terhadap masyarakat sudah baik. Hal ini juga diakui oleh masyarakat, dimana masyarakat selama ini merasa puas terhadap pelayanan perangkat desa.

Pelayanan umum yang telah diberikan oleh perangkat desa diwilayah sampel memiliki kesamaan antara desa satu dengan desa lainnnya yaitu perwujudan dalam pelayanan di bidang administratif dan non administrative. Pelayanan bidang administrasi umum (kegiatan pencatatan data mengenai kegiatan-kegiatan pemerintah desa), administrasi penduduk (kegiatan pencatatan data penduduk pada buku administrasi penduduk), administrasi keuangan (kegiatan pencatatan data mengenai penerimaan dan pengeluaran keuangan desa pada buku administrasi keuangan desa), dan administrasi pembangunan.

Kemampuan perangkat desa dalam pelayanan publik belum diikuti secara baik dalam administrasi seperti dalam mengatur dan menyelenggarakan pencatatan buku-buku, karena kurang teratur dan kurang tertib serta belum sistematis. Keterbatasan kemampuan perangkat desa dalam pelayanan administrasi karena mereka belum pernah mendapat diklat/bintek yang memadai.

\section{3) Kemampuan Manajemen Aset}

Sistem manajemen aset pemerintah desa sejak diberlakukannya undang-undang pemerintahan daerah mengalami banyak perubahan, dimana pemerintah desa dituntut untuk mengelola aset yang efektif dalam pengadaan dan pengelolaan, efisien dalam pemanfaatan dan pemeliharaan, serta transparan dan dapat dipertanggungjawabkan.

Beban yang harus dilaksanakan pemerintah desa tersebut tidak sesuai dengan pembinaan yang mereka terima. Seperti rendahnya diklat/penataran/bintek peningkatan kemampuan manajemen aset yang diikuti perangkat desa, yaitu hanya $23,1 \%$, dan yang belum pernah mengikuti mencapai $76,9 \%$. Walaupun mayoritas perangkat desa belum mengikuti diklat/penataran/bintek peningkatan kemampuan manajemen asset, namun demikian mereka merasa sudah memiliki pengetahuan manajemen asset, yang memadai, hal ini tersermin $38,5 \%$ cukup memahami, dan $26,9 \%$ sudah memahami.

Mayoritas persepsi perangkat desa terhadap mengelola asset desa (manajemen aset desa) tersebut disebabkan pengertian pengelolaan asset desa yang dipahami perangkat desa terbatas pada menjaga, mencatat asset-asset desa agar tidak terjadi perubahan status kepemilikan, baik untuk kepentingan publik maupun perorangan. Pemahaman manajemen aset desa yang sederhana 
tersebut disebabkan keberadaan perangkat desa semanjak diangkat menjadi perangkat desa sampai saat ini belum pernah mendapatkan diklat/bintek yang memadai. Sehingga konsep-konsep manajemen aset desa tidak diketahui dengan baik.

Perangkat desa dalam mengelola aset desa belum berfikir asset desa dikelola untuk kepentingan desa melalui upaya-upaya inventarisasi, pengembangan serta pendistribusiannya kembali. Tanah bengkok atau bondo desa pengelolaannya selama ini hanya disewakan, yang hasilnya dialokasikan untuk gaji kepala desa dan perangkat desa. BUMDes yang merupakan asset desa sebagai sumber pendapatan asli desa potensial belum dikembangkan dan dikelola dengan baik.

\section{4) Kemampuan Manajemen Keuangan}

Dalam penyelenggaraan pemerintahan desa, perangkat desa dituntut untuk memiliki kemampuan manajemen keuangan desa yang memadai. Namun demikian tingkat keikutsertaan perangkat desa dalam mengikuti diklat/penataran/bintek peningkatan kemampuan manajemen keuangan masih rendah, yaitu $23,1 \%$, dan yang belum pernah mengikuti mencapai $76,9 \%$.

Dilihat dari tingkat keikutsertaan perangkat desa dalam mengikuti diklat/ penataran/bintek peningkatan kemampuan manajemen keuangan masih rendah tersebut, tetapi mayoritas perangkat desa merasa sudah memiliki pengetahuan manajemen keuangan desa yang memadai, yaitu 42,3\% informan kepala desa menyatakan kalau tingkat pengetahuannya sudah memadai, 30,8\% cukup memadai, dan yang menyatakan kurang memadai dan tidak jawab/tidak tahu masingmasing hanya $19,2 \%$ dan $7,4 \%$.

Berdasarkan hasil pengamatan dan wawancara, perangkat desa belum memiliki kemampuan dalam pengelolaan keuangan desa secara baik. Hal ini berdampak pada lemahnya pelaksanaan manajemen keuangan dan kekayaan desa. Dalam pelaksanaan perencanaan keuangan daerah, walaupun semua desa sudah menyusun APBDes, dalam menentukan besarnya penganggaran dapat menentukan skala prioritas serta distribusi sumber daya dengan baik, tetapi dalam pelaksanaan dan penatausahaan keuangan desa, serta administrasi desa belum terselenggara dengan baik. Pelaporan dan pertanggungjawaban keuangan desa juga belum dilakukan dengan baik. Dalam manajemen kekayaan desa, banyak dijumpai barang-barang kekayaan desa yang belum terpelihara dengan baik. Pengelolaan potensi desa untuk menambah pendapatan desa dapat dikatakan juga masih belum optimal. Badan Usaha Milik Desa yang diharapkan bisa meningkatkan pendapatan asli desa belum terkelola dengan baik. Akhirnya, dari sisi penerimaan keuangan desa masih sangat bergantung dari transfer pemerintah yang ada di atasnya.

\section{c. Kemampuan Teknis}

Pemerintah desa memiliki fungsi, menyelenggarakan rumah tangga desa, melaksanakan pembangunan dan pembinaan kemasyarakatan, melaksanakan pembinaan perekonomian desa, melaksanakan pembinaan partisipasi dan swadaya gotong royong masyarakat, melaksanakan pembinaan ketentraman dan ketertiban masyarakat, dan melaksanakan musyawarah penyelesaian perselisihan dan lain sebagainya. Untuk dapat melaksanakan fungsinya dengan baik perangkat desa sebagai pembantu kepala desa dalam menyelenggarakan pemerintahan desa dituntut untuk memiliki kemampuan teknis yang memadai, baik itu kemampuan teknis Administrasi Desa, Perencanaan Pembangunan, Anggaran, maupun kemampuan teknis Pelayanan Publik.

Perangkat desa yang sudah mengikuti diklat/penataran/bintek peningkatan kemampuan teknis masih sangat rendah, yaitu dari 104 informan perangkat desa hanya $17,3 \%$ yang pernah mengikuti diklat/penataran/bintek, dan perangkat desa yang belum mengikuti diklat/penataran/bintek peningkatan kemampuan teknis sebesar $82,7 \%$. Adapun yang pernah mengikuti diklat/penataran/bintek Administrasi Desa 4 orang, Perencanaan Pembangunan 4 orang, anggaran 5 orang, dan yang pernah mengikuti diklat/penataran/bintek Pelayanan Publik 5 orang. Sedangkan yang belum pernah mengikuti diklat/penataran/bintek Administrasi Desa 26 orang, Perencanaan Pembangunan 26 orang, anggaran 26 orang, dan yang pernah mengikuti diklat/penataran/ bintek pelayanan publik 26 orang.

Mayoritas persepsi perangkat desa terhadap tingkat pengetahuan teknis (administrasi desa, perencanaan pembangunan, anggaran dan pelayanan publik) perangkat desa cukup memadai, yaitu: $63,4 \%$ tingkat pengetahuan dasar perangkat desa dinilai cukup memahami, 20,2\% sudah memahami, 8,7\% perangkat desa kurang memahami pengetahuan dasar terkait dengan, dan 7,7\% menyatakan tidak tahu.

\section{1) Kemampuan Teknis Administrasi Desa}

Tingkat keikutsertaan perangkat desa dalam mengikuti diklat/penataran/bintek peningkatan kemampuan teknis mayoritas masih rendah, yaitu dari perangkat desa dari 26 desa, yang sudah mengikuti diklat/penataran/bintek kemampuan teknis hanya $15,4 \%$, yang belum mengikuti mencapai $84,6 \%$.

Persepsi perangkat desa terhadap kapasitas perangkat desa dalam penyelenggaraan pemerintahan desa dilihat dari pengetahuan teknis, tingkat pengetahuan perangkat desa sudah cukup 
baik $76,9 \%$, sudah baik $11,5 \%$, kurang baik $3,9 \%$, dan tidak tahu $7,4 \%$.

Persepsi perangkat desa terhadap kemampuan teknis administrasi desa cukup baik pada dasarnya dapat dipahami. Karena perangkat desa rata-rata sudah lebih dari 10 (sepuluh) tahun melaksanakan berbagai rangkaian kegiatan pemerintahan desa. Namun demikian kemampuan teknis tersebut kurang ditunjang dengan pengetahuan perangkat desa melalui diklat/kursus yang mampu meningkatkan kemampuan teknisnya. Berbagai regulasi kebijakan desa telah diambil, baik oleh pemerintah, pemerintah provinsi maupun pemerintah kabupaten akan berpengaruh terhadap kemampuan teknis perangkat desa. Namun demikian kondisi ini kurang diantisipsi oleh pemerintah daerah. Berbagai kegiatan yang dapat meningkatkan kompetensi, seperti diklat/kursus yang seharusnya diberikan kepada perangkat desa ternyata belum dilaksanakan.

\section{2) Kemampuan Teknis Perencanaan Pembangunan}

Tingkat keikutsertaan perangkat desa dalam mengikuti diklat/penataran/ bintek peningkatan kemampuan teknis perencanaan pembangunan hanya $15,4 \%$, dan yang belum pernah ikut mencapai $84,6 \%$. Kondisi ini menunjukkan bahwa kurangnya pembinaan peningkatan kemampuan teknis perencanaan pembangunan bagi perangkat desa, baik yang dilkaukan pemerintah kabupaten maupun pemerintah provinsi.

Mayoritas persepsi perangkat desa terhadap pemahaman teknis perencanaan pembangunan mmemadai, dimana $57,7 \%$ cukup memahami dan $23,1 \%$ memahami, sedangkan $11,5 \%$ kurang memahami dan tidak tahu 7,4\%.

Persepsi perangkat desa cukup baik terhadap tingkat kemampuan teknis perencanaan pembangunan desa pada dasarnya hanya pemahaman kegiatan musrenbang yang rutin dilaksanakan setiap tahun. Tetapi pemahaman perangkat desa terhadap proses perencanaan sebagaimana diatur dalam PP Nomor 72 Tahun 2005 dijelaskan bahwa proses penyusunan perencanaan pembangunan desa harus dilaksanakan secara partisipasif dan melibatkan lembaga kemasyarakatan desa. Lebih lanjut dalam pasal 64 dijelaskan, bahwa 1) rencana pembangunan desa disusun secara berjangka, meliputi: 1) rencana pembangunan jangka menengah Desa (RPJMDes) untuk jangka waktu 5 (lima) tahun; dan 2) rencana kerja pembangunan desa (RKP Desa), yang merupakan penjabaran dari RPJMDes untuk waktu 1 (satu) tahun. 2) RPJMDes ditetapkan dengan Peraturan Desa, dan RKP ditetapkan dalam Keputusan Kepala Desa berpedoman pada peraturan daerah, masih kurang.
Kurangnya kemampuan teknis perencanaan pembangunan desa, tercermin dari dokumendokumen perencanaan desa yang belum lengkap. Belum semua desa menyusun RPJMDes, namun demikian desa sudah menyusun RKP Desa, padahal untuk menyusun RKP Desa seharusnya mengacu pada RPJMDes. Tersusunnya RKP Desa tersebut menimbulkan tanda tanya, bagaimana mungkin Desa dapat menyusun RKP Desa, sedangkan RPJMDes belum mereka susun. Selain itu pelaksanaan Musrenbang Desa di beberapa desa kajian tidak berlangsung secara optimal. Adanya keterbatasan anggaran juga berpengaruh besar pada penyusunan anggaran pendapatan dan belanja desa (APBDes). Adanya loncatan-loncatan dalam penyusunan dokumen perencanaan pembangunan tersebut memperlihatkan, bahwa pada dasarnya pemahaman teknis perencanaan pembangunan desa yang dimiliki perangkat desa belum memadai karena perangkat desa belum dibekali dengan diklat/bintek yang diperlukan, sehingga perangkat desa hanya melakukan kegiatan-kegiatan secara rutin seperti tahun-tahun sebelumnya, padahal kebijakan mekanisme perencanaan pembangunan desa sudah mengalami perubahan yang sangat mendasar.

\section{3) Kemampuan Teknis Anggaran}

Dari tabel 8 diketahui bahwa, tingkat keikutsertaan perangkat desa dalam mengikuti diklat/penataran/bintek peningkatan kemampuan teknis anggaran hanya $19,2 \%$, dan yang belum pernah mengikuti mencapai $80,8 \%$.

Tabel 9 menunjukkan bahwa, persepsi perangkat desa terhadap tingkat pengetahuan perangkat desa terhadap teknis anggaran cukup memadai. Hal ini tercermin 38,5\% menyatakan cukup memahami, 26,9\% menyatakan sudah memahami, sedangkan yang menyatakan masih kurang dan tidak tahu masing-masing $15,4 \%$ dan $19,2 \%$.

Persepsi perangkat desa terhadap tingkat kemampuan teknis anggaran yang dimilikinya cukup baik. Perangkat desa sudah menyadari kalau pengelolaan keuangan desa adalah unsur penting bagi desa karena mempunyai tujuan mensejahterakan rakyat dengan memaksimalkan pencarian sumber pendapatan sebagai modal atau dana didalam perencanaan anggaran pendapatan dan belanja desa. Keuangan Desa mengatur tentang sumber pendapatan desa, yaitu berdasarkan pendapatan asli desa, kemudian bantuan dari Pemerintah Kabupaten berupa bagian yang diperoleh dari pajak dan retribusi serta bagian dari dana perimbangan keuangan pusat dan daerah yang diterima oleh Pemerintah Kabupaten, selain itu bantuan dari Pemerintah dan Pemerintah Provinsi, sumbangan pihak ketiga dan pinjaman desa. Namun demikian beberapa hal yang dimuat dalam keuangan desa ini merupakan hal yang baru 
Tabel 8. Keikutsertaan Perangkat Desa Terhadap Diklat/Penataran/ Bintek Peningkatan Kemampuan Teknis

\begin{tabular}{|c|c|c|c|c|c|c|c|c|c|}
\hline & \multirow{3}{*}{ Diklat/Penataran/Bintek } & \multicolumn{6}{|c|}{ Frekwensi Jawaban Responden } & \multirow{2}{*}{\multicolumn{2}{|c|}{ Total }} \\
\hline & & \multicolumn{2}{|c|}{ Sudah } & \multicolumn{2}{|c|}{ Belum } & \multicolumn{2}{|c|}{$\begin{array}{c}\text { Tidak } \\
\text { Jawab/Tahu }\end{array}$} & & \\
\hline & & Jlh & $\%$ & Jlh & $\%$ & Jlh & $\%$ & Jlh & $\%$ \\
\hline 1 & Administrasi Desa & 4 & 15,4 & 22 & 84,6 & - & - & 26 & 100,0 \\
\hline 2 & Perencanaan Pembangunan & 4 & 15,4 & 22 & 84,6 & - & - & 26 & 100,0 \\
\hline 3 & Anggaran & 5 & 19,2 & 21 & 80,8 & - & - & 26 & 100,0 \\
\hline 4 & Pelayanan Publik & 5 & 19,2 & 21 & 80,8 & - & - & 26 & 100,0 \\
\hline \multicolumn{2}{|c|}{ Kemampuan Teknis } & 18 & 17,3 & 86 & 82,7 & - & - & 104 & 100,0 \\
\hline
\end{tabular}

Tabel 9. Persepsi Perangkat Desa Terhadap Tingkat Pengetahuan Teknis

\begin{tabular}{|c|c|c|c|c|c|c|c|c|c|c|c|}
\hline \multirow{3}{*}{\multicolumn{2}{|c|}{ Diklat/ Penataran/Bintek }} & \multicolumn{8}{|c|}{ Frekwensi Jawaban Responden } & \multirow{2}{*}{\multicolumn{2}{|c|}{ Total }} \\
\hline & & \multicolumn{2}{|c|}{ Memahami } & \multicolumn{2}{|c|}{ Cukup } & \multicolumn{2}{|c|}{ Kurang } & \multicolumn{2}{|c|}{$\begin{array}{c}\text { Tidak } \\
\text { Jawab/Tahu }\end{array}$} & & \\
\hline & & Jlh & $\%$ & Jlh & $\%$ & Jlh & $\%$ & Jlh & $\%$ & Jlh & $\%$ \\
\hline 1 & Administrasi Desa & 3 & 11,5 & 20 & 76,9 & 1 & 3,9 & 2 & 7,4 & 26 & 100,0 \\
\hline 2 & $\begin{array}{l}\text { Perencanaan } \\
\text { Pembangunan }\end{array}$ & 6 & 23,1 & 15 & 57,7 & 3 & 11,5 & 2 & 7,4 & 26 & 100,0 \\
\hline 3 & Anggaran & 5 & 19,2 & 15 & 57,7 & 4 & 15,4 & 2 & 7,4 & 26 & 100,0 \\
\hline 4 & Pelayanan Publik & 7 & 26,9 & 16 & 61,5 & 1 & 3,9 & 2 & 7,4 & 26 & 100,0 \\
\hline \multicolumn{2}{|c|}{ Kemampuan Teknis } & 21 & 20,2 & 66 & 63,4 & 9 & 8,7 & 8 & 7,7 & 104 & 100,0 \\
\hline
\end{tabular}

Sumber: Data Primer

bagi perangkat desa karena selama ini mereka belum terbiasa untuk berkreasi mencari pendapatan asli desa. Mekanisme pengelolaan keuangan desa merupakan suatu kinerja manajemen dalam pelaksanaan anggaran pendapatan dan belanja desa (APBDes) yang disusun secara berantai.

Di dalam APBDes sudah tercantum daftar belanja dan rencana pengeluaran desa selama satu tahun kedepan. Sumber kas desa antara lain diperoleh dari pelayanan-pelayanan desa serta retribusi. Diproyeksikan bahwa pendapatan desa dialokasikan untuk anggaran rutin/ pegawai diperuntukkan bagi pemerintah desa dan BPD. Kemudian anggaran juga akan diberikan untuk PKK, pelaksanaan musyawarah, pembangunan desa, lembaga pemberdayaan masyarakat desa, kegiatan olahraga serta pembangunan fisik. Sementara dana untuk membiayai pengeluaran belanja langsung, antara lain untuk belanja pegawai/honorarium, belanja barang dan jasa dan belanja modal. Dan untuk pengeluaran belanja tidak langsung, yaitu belanja penghasilan tetap, belanja tunjangan, belanja hibah kepada kelompok masyarakat, belanja bantuan sosial, belanja bantuan keuangan kepada lembaga dan belanja tidak terduga.

\section{4) Kemampuan Teknis Pelayanan Publik}

Dari tabel 8 diketahui bahwa, tingkat keikutsertaan perangkat desa dalam mengikuti diklat/penataran/bintek peningkatan kemampuan teknis pelayanan publik hanya $19,2 \%$, dan yang belum pernah mengikuti mencapai $80,8 \%$.

Sedangkan dari tabel 9 diketahui bahwa, persepsi perangkat desa terhadap tingkat pengetahuan perangkat desa terhadap teknis pelayanan publik sudah cukup baik, dimana dari 26 informan perangkat desa $61,5 \%$ menyatakan sudah cukup baik, 26,9\% menyatakan sudah baik, sedangkan yang menyatakan masih kurang dan tidak tahu masing-masing 3,9\% dan 7,4\%.

Konsep manajemen pelayanan publik paling tidak harus menyangkut aspek: (1) transparansi; (2) prosedur yang sederhana dan tidak berbelitbelit, mudah dipahami dan mudah dilaksanakan, serta diwujudkan dalam bentuk bagan alir yang dipampang dalam ruangan pelayanan; (3) persyaratan teknis dan administratif pelayanan; (4) rincian biaya pelayanan, yang memuat kepastian dan rincian biaya pelayanan publik harus diinformasikan secara jelas dan diletakkan di dekat loket pelayanan, serta setiap pungutan yang ditarik dari masyarakat harus disertai dengan tanda bukti resmi sesuai dengan jumlah yang dibayarkan; (5) waktu penyelesaian pelayanan adalah jangka waktu penyelesaian suatu pelayanan publik mulai dari dilengkapinya atau dipenuhinya persyaratan 
teknis dan atau persyaratan administratif sampai dengan selesainya suatu proses pelayanan; (6) menyusun standar pelayanan sesuai dengan tugas dan kewenangannya, dan dipublikasikan kepada masyarakat sebagai jaminan adanya kepastian bagi penerima pelayanan; (7) standar pelayanan yang merupakan ukuran kualitas kinerja yang dibakukan dalam penyelenggaraan pelayanan publik yang wajib ditaati oleh pemberi dan atau penerima pelayanan; (8) informasi pelayanan. Kapasitas pemahaman perangkat desa terhadap konsep manajemen pelayanan publik tersebut masih kurang. Mayoritas perangkat desa menyatakan belum memahami konsep manajemen, tetapi pada prinsipnya mereka menyatakan sudah melaksanakan sebagaian unsur tersebut, seperti prosedur pelayanan walaupun tidak dibuat bagan alir pelayanan yang dipasang di papan tulis, sudah menerapkan prosedur yang sederhana, mayoritas pelayanan yang diberikan adalah gratis/tidak dipungut biaya, sedangkan standar pelayanan belum dibuat secara formal.

Kemampuan perangkat desa dalam pelayanan kepada masyarakat belum tercermin dalam ketertiban administratif. Pemerintah daerah yang seharusnya memfasilitasi perangkat desa untuk meningkatkan kapasitas perangkat desa, baik melalui pembinaan, diklat maupun kursus belum banyak berperan secara baik. Keberadaan Balai Pemberdayaan Masyarakat Desa (Balai PMD) Di Yogyakarta juga belum mampu memberikan kesempatan perangkat desa diwilayah kerjanya untuk mengikuti diklat peningkatan kemampuan perangkat desa. Keterbatasan peran Pemda maupun Balai PMD disebabkan keterbatasan anggaran, sehingga fasilitasi dan pembinaan yang dilakukan oleh Pemda baru sebatas sosiliasi peraturan, rapat koordinasi dan surat edaran. Sedangkan keberadaan Balai PMD yang wilayah kerjanya relatif sangat luas tanpa diimbangi dengan SDM dan anggaran yang memadai.

\section{Aspek Kelembagaan}

Dalam pengangkatan perangkat desa, diwilayah kajian teridentifikasi, bahwa pemerintah Kabupaten Kudus berperan sebagai fasilitator, pembinaan dan monitoring, serta membuat regulasi aturan, yaitu Peraturan Daerah Kabupaten Kudus Nomor 20 Tahun 2006 Tentang Pengisian Dan Pemberhentian Perangkat Desa, sebagai pedoman pemerintah desa dalam melakukan rekrutmen perangkat desa. Dalam Perda tersebut antara lain mengatur pengisian lowongan sekretaris desa dilakukan oleh bupati dari pegawai negeri sipil yang memenuhi persyaratan. Sedangkan pengangkatan perangkat desa lainnya, dilakukan oleh Kepala Desa dengan membentuk Panitia Pengisian yang ditetapkan dengan Keputusan Kepala Desa.

\section{a. Ketentuan Formasi Pengangkatan Perangkat Desa}

Ketentuan formasi pengisian/pengangkatan perangkat desa, disesuaian dengan kebutuhan desa. Dalam Perda Kabupaten Kudus Nomor 20 Tahun 2006 Tentang Pengisian Dan Pemberhentian Perangkat Desa sudah diatur mengenai pengisian lowongan perangkat desa. Formasi Perangkat desa yang ada meliputi: Sekretaris Desa, Kepala Urusan (Kaur Pemerintahan, Kaur Pembangunan, Kaur Keuangan, kaur Kesejahteraan dan Kaur Umum), Pelaksana Teknis Lapangan, Unsur Kewilayahan (Kepala Dusun), Pembantu Kaur, Pembantu Pelaksana Teknis Lapangan, Pembantu Unsur Kewilayahan (Pembantu Kedus). Jumlah Formasi Pelaksana Teknis Lapangan, Unsur Kewilayahan (Kepala Dusun), Pembantu Kepala Urusan, Pembantu Pelaksana Teknis Lapangan, Pembantu Unsur Kewilayahan (Pembantu Kepala Dusun), disesuaikan dengan kebutuhan masing-masing desa, berdasarkan luas wilayah, mata pencaharian penduduk, dan potensi desa.

\section{b. Ketentuan Persyaratan Usia dan Pendidikan Rekrutmen Perangkat Desa}

Dalam Perda Kabupaten Kudus Nomor 20 Tahun 2006, diatur persyaratan rekrutmen/pengisian perangkat desa dan pemberhentian perangkat desa, yaitu persyaratan pendidikan, para calon perangkat desa harus berpendidikan paling rendah tamat Sekolah Menengah Pertama/Madrasah Tsanawiyah atau sederajat. Persyaratan umur paling rendah berumur 20 tahun dan paling tinggi berumur 45 tahun. Sedangkan masa pemberhentian perangkat desa pada usia 60 tahun.

Ketentuan tersebut sudah dilaksanakan hampir diseluruh desa. Namun demikian di desa kajian masih banyak dijumpai perangkat desa yang berpendidikan SD. Hal ini disebabkan perangkat desa yang ada merupakan orang lama, dimana dalam rekrutmennya belum ada ketentuan. Masa kerja perangkat desa mayoritas lebih dari 10 (sepuluh) tahun.

\section{c. Struktur Organisasi dan Tata kerja Pemerintahan Desa}

Kapasitas perangkat desa dalam menyelenggarakan pemerintahan desa sangat dipengaruhi oleh institusi/kelembagaan pemerintahan desa. Kelembagaan pemerintah desa, dalam kajian ini dilihat dari struktur organisasi dan tata kerja pemerintahan desa, tugas dan fungsi perangkat desa, proses pengambilan keputusan dalam organisasi pemerintahan desa, prosedur dan mekanisme kerja dalam organisasi pemerintahan desa, dan kebijakan/peraturan yang telah dikeluarkan oleh pemerintahan desa.

Struktur organisasi dan tata kerja pemerintahan desa diatur dalam Perda Kabupaten Kudus Nomor 13 Tahun 2006 Tentang Pedoman Penyusunan Organisasi Dan Tata Kerja Pemerintahan Desa. Berdasarkan Perda tersebut, terdapat keseragaaman 
struktur oerganisasi dan tata kerja pemerintahan desa. Yang membedakan adalah jumlah perangkat yang berasal dari unsur kewilayahan dan unsur pelaksana teknis lapangan, yang disesuaikan dengan kebutuhan masing-masing desa.

Jumlah perangkat desa dalam suatu desa bervariasi, karena dalam Perda ataupun peraturan perundangan yang lebih tinggi tidak diaturan secara jelas jumlah perangkat desa yang diperbolehkan. Penentuan jumlah perangkat desa tidak ada standart jelas. Masing-masing desa dalam menentukan jumlah perangkat berdasarkan atas budaya lokal, dimana jumlah tersebut sudah ada sebelum ada UU Nomor 5 Tahun 1979.

Struktur organisasi dan tata kerja pemerintahan desa di Kabupaten Kudus belum mengacu sepenuhnya pada UU Nomor 32 tahun 2004 tentang Pemerintahan Daerah dan PP Nomor 72 Tahun 2005 tentang Desa. Struktur organisasi dan tata kerja pemerintahan desa memiliki kemiripan dengan struktur organisasi dan tata kerja pemerintahan desa yang diatur dalam UU Nomor 5 tahun 1979 tentang Pemerintahan Desa.

Dalam menyusun struktur organisasi dan tata kerja pemerintahan desa Bagian Pemerintahan Sekretaris daerah Kabupaten Kudus menapsirkan kalau kepala urusan merupakan unsur sekretaris desa, unsur pelaksana teknis lapangan adalah kebayan ladu, modin, pembantu modin, dan unsur kewilayahan adalah kepala dusun dan pembantu kepala dusun. Sedangkan untuk dalam UU Nomor 32 Tahun 2004, disebutkan bahwa unsur staf, yaitu unsur pelayanan kesekretariatan (sekretaris desa), unsur pelaksana teknis, yaitu kepala urusan yang terdiri dari kepala urusan pemerintahan, kepala urusan pembangunan dan kepala urusan pelayanan umum, dan unsur wilayah, yaitu kepala dusun, yang membantu kepala desa di wilayah bagian desa.

\section{Aspek Sarana dan Prasarana Kantor Desa}

Sarana dan prasarana kantor desa memiliki pengaruh langsung dan pengaruh ikutan terhadap kemampuan perangkat desa dalam penyelenggaraan pemerintahan desa. Peralatan kantor pemerintahan desa yang tersedia baru sebatas peralatan meubelir. Dari kemanfaatan peralatan kantor desa yang mampu menunjang kemampuan perangkat desa masih sangat terbatas sekali, seperti ketersediaan kompiuter/laptop, sepeda motor, dll. Pemerintah desa tidak memiliki kapasitas dalam pengadaan peralatan tertentu, seperti kompiuter/laptop, sepeda motor. Karena peralatan tersebut diperoleh dari pemerintah kabupaten. Pengajuan kebutuhan peralatan kantor desa yang diajukan ke pemerintah daerah sulit terealisasi. Fasilitas internet, sebagai sarana belajar perangkat desa untuk meningkatkan kapasitanya/ kemampuannya belum tersedia.

\section{Kendala-Kendala Meningkatkan Kapasitas Perangkat Desa}

Masa kerja perangkat desa yang terlalu lama dan berusia tua, menyebabkan kejenuhan dalam bekerja dan menurunnya motivasi untuk belajar. Disamping itu keterbatasan anggaran merupakan masalah utama yang dihadapi untuk meningkatkan kemampuan/ kapasitas perangkat desa. Berbagai agenda yang telah dususun baik pemerintah provinsi, kabupaten, maupun pemerintah desa untuk meningkatkan kemampuan perangkat desa tidak dapat terealisasikan karena anggaran untuk peningkatan SDM sangat kecil. Adanya keterbatasan program-program pelatihan, bintek, sosialisasi, serta terbatasnya tenaga nara sumber, serta kurang jelasnya tanggungjawab perangkat desa dalam melaksanakan tugas dan fungsinya, karena tugas yang diberikan oleh Kades tidak sesuai dengan tugas dan fungsinya. Disamping itu tingkat kesejahteraan perangkat desa masih rendah disebabkan Desa tidak mempunyai kas untuk menunjang, kesejahteraan perangkat desa dan penghasilan yang kurang memadai, tanah bengkok banyak yang tidak produktif, uang tambahan kesejahteraan dari kabupaten belum sesuai UMR, sedangkan tunjangan dari bagian dana perimbangan yang diberikan kepada desa setiap tahunnya belum sesuai. Tingkat kesejahteraan perangkat desa yang masih rendah menyebabkan perangkat desa cenderung untuk mencari tambahan penghasilan dan kurang memikirkan untuk meningkatkan kapasitasnya sebagai perangkat desa.

\section{Upaya-Upaya Meningkatkan Kapasitas Perangkat Desa}

\section{Upaya-Upaya yang Telah Dilaksanakan}

Belum banyak upaya yang telah dilakukan oleh pemerintah Kabupaten Kudus maupun pemerintah desa untuk meningkatkan kapasitas perangkat desa. Upaya-upaya yang telah pemerintah desa dilakukan masih terbatas pada penyusunan dan pengajuan proposal untuk mendapatkan pelatihan bagi perangkat desa ke Pemda (Bagian pemerintahan Sekretaris Daerah Kabupaten), Sudah beberapa kali tahun anggaran pemerintah desa mengajukan proposal, namun demikian belum ada tanggapan dari pemda sampai saat ini. Upaya nyata pemerintad desa hanya sebatas rapat- intern. Demikian halnya dengan Pemerintah Kabupaten maupun kecamatan belum ada upaya nyata yang diterima oleh perangkat desa. Langkah nyata yang telah dilakukan oleh Pemda sebatas pembinaan melalui Surat Edaran Bupati, pemberian buku pedoman penyusunan administrasi desa.

\section{Upaya-Upaya yang Akan Dilaksanakan}

Pemerintah desa, tidak memiliki posisi tawar yang cukup untuk melakukan upaya-upaya peningkatan kemampuan perangkat desa. Sebab keputusan dapat melakukan atau tidak upaya-upaya peningkatan kemampuan perangkat desa yang 
menentukan Pemda. Pemerintah Desa sudah apatis terhadap peningkatan kemampuan perangkat desa, sebab sudah beberapa kali tahun anggaran pemerintah desa mengajukan penyelenggaraan diklat dan bintek bagi perangkat desa ke Pemda, tetapi kurang mendapat respon positif dari Pemda. Upaya-upaya yang akan pemerintah desa untuk meningkatkan kemampuan perangkat desa, mengajukan kembali ke Pemda, agar Pemda melakukan pembinaan, diklat, bintek perangkat desa, baik yang dilaksanakan oleh Pemda sendiri, pembinaan rutin tiap bulan di kecamatan terkait teknis penyusunan pembukuan/buku kas desa, ataupun mengirim perangkat desa untuk mengikuti pelitahan di Balai PMD di Yogyakarta. Melakukan sosialisasi regulasi desa dan bimbingan teknis penyusunan regulasi desa. Pemda/kecamatan Mengadakan Rakor Perangkat Desa secara periodik. Memberikan nara sumber dan pendampingan dalam kegiatan Musrenbang.

Upaya-upaya yang akan dilakukan Pemerintah desa, sesuai dengan kewenangan yang dilaksanakan selama ini hanya sebatas menghimbau perangkat desa untuk meningkatkan minat baca peraturan perundangan dengan membagikan peraturan perudangan-undangan dan pedoman/juknis terkait dengan pemerintahan desa. Melakukan rapat inter secara periodik. Menyarankan dan mendorong perangkat desa khususnya yang berusia muda untuk menempuh pendidikan formal yang lebih tinggi (Ijin Belajar).

Diskripsi pembinaan kapasitas perangkat desa tidak tergambarkan dengan baik, sistem pembinaan yang dilakukan Pemda Kabupaten Kudus, sehingga kurang dapat membantu pemerintah desa dalam meningkatkan kapasitas perangkat desa.

\section{SIMPULAN}

Kapasitas Perangkat Desa: (1) Tingkat pendidikan dan masa kerja perangkat desa sudah memadai, yaitu 73,7 perangkat desa berpendidikan SLTP s/d SLTA, dan 97,9\% memiliki masa kerja lebih dari 10 tahun; (2) Keikutsertaan perangkat desa dalam diklat/penataran/bintek kompetensi masih sangat rendah, dimana $82,1 \%$ perangkat desa belum mengikuti diklat/penataran/bintek peningkatan kemampuan dasar, $79,8 \%$ perangkat desa belum mengikuti diklat/penataran/bintek peningkatan kemampuan manajemen, dan $82,7 \%$ perangkat desa belum mengikuti diklat/penataran/bintek peningkatan kemampuan teknisp; (3) Kapasitas perangkat desa dalam menyusun regulasi desa, baik dalam hal perencanaan, pelaksanaan, maupun dalam penyusunan Perdes dan Keputusan Kepla Desa masih kurang; tingkat pemahaman perangkat desa dalam memahami majemen sumber daya manusia (SDM) masih kurang. Kemampuan teknis perangkat desa masih kurang, seperti adanya loncatan-loncatan dalam penyusunan dokumen perencanaan pembangunan; (4) Dalam penyelenggaraan pemerintahan desa, perangkat desa sudah didukung kelembagaan pemerintahan desa yang memadai; dan (5) Dalam penyelenggaraan pemerintahan desa, perangkat desa belum didukung sarana dan prasarana kantor desa yang memadai.

Masalah keterbatasan anggaran merupakan kendala utama meningkatkan perangkat desa. Rendahnya alokasi anggran berdampak pada kegiatan dan program peningkatan kapasitas perangkat desa tidak dapat terealisasi. Komitmen Pemda dalam peningkatan kapasitas perangkat desa masih rendah. Peran penting pembinaan baru terbatas pada regulasi kebijakan pemerintahan desa tanpa didukung SDM dan alokasi dana yang memadai. Balai PMD sebagai instansi yang menyelenggarakan diklat dan bintek bagi perangkat desa maupun masyarakat desa belum mampu melaksanakan tugas dan fungsinya secara optimal, karena wilayah Balai PMD yang sangat luas dengan dukungan sumber daya yang terbatas.

Upaya-upaya yang telah dan rencana ke depan untuk meningkatkan kapasitas perangkat desa yang dilakukan Pemda Kabupaten Kudus masih rendah, sehingga kurang dapat membantu pemerintah desa dalam meningkatkan kapasitas perangkat desa

\section{Saran}

Perlunya mengadakan pelatihan dan sosialisasai Peraturan, mengadakan pelatihan terkait pelayanan publik, management aset dan keuangan desa dan sosialisasai Peraturan. Strategi yang dapat dikembangkan adalah, peningkatan melalui bimbingan teknis manajemen keuangan desa yang mencakup penyusunan APBDesa, Pengelolaan ADD, Pengelolaan Kekayaan Desa, Pengelolan BUMDes. Selain itu perlunya sosialisasi peraturan kebijakan keuangan desa melalui pendampingan maupun fasilitasi, misalnya dalam pendirian BUMDes, dan sebagainya. Strategi untuk meningkatkan kapasitas aparatur desa dalam bidang pelayanan kepada masyarakat diantaranya adalah perlu adanya peningkatan kemampuan aparat desa dalam merumuskan program-program pelayanan. Selain itu peningkatan kemampuan dalam mengelola pelayanan termasuk pengetahuan teknis administratif (formatformat pelayanan administrasi dsb) dan kemampuan memahami petunjuk maupun peraturan undangundang yang mendukung aparatur desa dalam memberikan pelayanan, selain kemampuan teknis penunjang (mengoperasikan komputer). Perlunya penyusunan modul-modul yang berkaitan dengan perumusan kebijakan. Perlunya kerja sama antara BPP Kemendari dengan Dirjen PMD melakukan pemetaan kapasitas perangkat desa lebih lanjut untuk desa diseluruh Indonesia untuk data base kapasitas perangkat desa sebagai bahan perumusan modulmodul pelatihan perangkat desa pada Balai PMD. Jumlah Balai PMD perlu ditambah dan disertai anggaran yang memadai. 


\section{DAFTAR PUSTAKA}

Abdurrahmat Fathoni (2006) "Organisasi dan Manajemen sumber Daya Manusia”. Rineka Cipta: Jakarta.

Anonim, 2002, Kerangka Nasional Pengembangan dan Peningkatan Kapasitas Pemerintah Dalam Rangka Mendukung Desentralisai. Kebijakan Menteri Dalam Negeri dan Kepala Bappenas.

Arikunto, S (2002) "Prosedur Penelitian: Suatu Pendekatan Praktek", Jakarta: Rineka Cipta.

Bungin, Burhan (2003) "Analisis Data Penelitian Kualitatif”, Jakarta: PT Raja Grafindo Persada.

Care Internasional Indonesia, 2004, Pedoman Peningkatan Kapasitas Pemerintahan Desa, Samarinda: Care Internasional Indonesia.

Desler, Gary (1993) “Manajemen Personalia”. Erlangga: Jakarta

Flippo, Edwin B (1995) "Manajemen Personalia" Erlangga.

Hasibuan S.P Malayu, 2005, Manajemen Sumber Daya Manusia, Jakarta: PT. Bumi Aksara.

Gomes, Faustino Cardoso, (1995) "Manajemen sumber Daya Manusia", Andi Offset: Yogyakarta.

Kartono, Kartini. 1993 "Pemerintahan dan Kepemimpinan", Rajawali Press: Jakarta.

Lipton dan Moore (1980) "Metodologi studi Pedesaan di Negara-Negara Berkembang”, Yayasan Ilmu-ilmu Sosial, Jakarta.

Peraturan Pemerintah Nomor 72 Tahun 2005 tentang Desa

Peraturan Presiden Nomor 59 Tahun 2012 Tentang Kerangka Nasional Pengembangan Kapasitas Pemerintahan Daerah.

Putri,Vera Jasini, 2005, Kamus Hukum dan Glosarium Otonomi Daerah, Jakarta: Friedrich Naumann Stiftung.

Rasyid, M. 1992, "Pembangunan Kualitas dan UsahaUsaha Peningkatan Aparatur Pemerintah", Universitas Tadulako Palu

Sedarmayati, 2007, Manajemen Sumber Daya Manusia, Reformasi Birokrasi dan manajemen Pegawai Negeri Sipil, Bandung: PT. Refika Aditama.

Syarif, Roesli, 1991, "Teknik Manajemen Latihan dan Pembinaan", Bina Aksara. Bandung

Tjiptoherianto, Prijono, 1993, "Pembangunan Sumber Daya Manusia", Prisma. Jakarta

Undang-Undang Nomor 32 Tahun 2004 tentang Pemerintahan Daerah.

UNDP, 1997, Capacity Assessment and Development.

http://kejobongkec.blogspot.com/2011/10/kapasitasaparatur-desa.html

http://melung.desa.id/2014/02/15/penguatan-kapasitaskelembagaan/

http://suryokocolink.wordpress.com/2010/10/11/peningk atan-kapasitas-pemerintah-desa/ 
